\title{
Otel İşletmelerinde Bilgi/Deneyim Paylaşım Süreci: Bir Ölçek Geliştirme Çalışması
}

\section{Knowledge/Experience Sharing Process in Hotel Establishments: A Scale Development Study}

\author{
Oğuz Türkay ${ }^{a}$, Melih Kabadayı ${ }^{\text {b,* }}$ \\ a Prof. Dr., Sakarya Uygulamalı Bilimler Üniversitesi, Turizm Fakültesi, Gastronomi ve Mutfak Sanatları Bölümü, 54600, Sakarya/Türkiye. \\ ORCID: 0000-0002-0752-6799

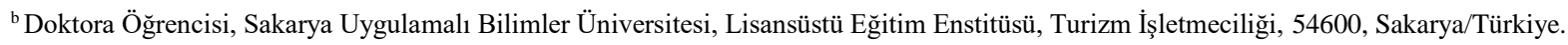 \\ ORCID: 0000-0002-8521-6999
}

\section{MAKALE BİLGISİ}

Makale Geçmişi:

Başvuru tarihi: 01 Kasım 2020

Düzeltme tarihi: 12 Mart 2021

Kabul tarihi: 21 Mart 2021

Anahtar Kelimeler:

Bilgi/Deneyim paylaşımı

Örgütsel öğrenme

Örgütsel hafiza

Otel işletmeleri

Ölçek geliştirme.
ÖZ

$\mathrm{Bu}$ çalışmanın amacı, otel işletmelerinde örgütsel hafiza ve örgütsel öğrenme olgularının gelişiminde önemli bir role sahip olan, bilgi/deneyim paylaşımı ile ilgili geçerli ve güvenilir bir ölçek geliştirmektir. Deneyim paylaşım sürecinin ne, neden ve nasıl'ına yanıt üretecek şekilde deneyim paylaşım güdüleri, deneyim paylaşım kanalları ve paylaşılan deneyim türlerini kapsayan 30 ifadenin tutarlı bütünselliği, 2015-2016 yıllarında 333 otel çalışanından elde edilen veri üzerinden değerlendirilmiştir. Ölçeğin kapsam geçerliği uzman görüşleri aracılı̆̆ıyla, yap1 geçerliği ise Açımlayıcı Faktör Analizi (AFA) ve Doğrulayıcı Faktör Analizi (DFA) kullanılarak değerlendirilmiştir. Güvenirliğin belirlenmesinde ise Cronbach Alpha, Rho-A ve Composite Reliability ve Fornell-Larcker Criterion değerleri incelenmiştir. Gerçekleştirilen analizler sonucunda ölçülen yapının geçerli ve güvenilir bir ölçme aracı olduğu tespit edilmiştir.

\section{ARTICLE INFO}

\section{Article history:}

Received: November 01, 2020

Received in revised form: May 12, 2021

Accepted: May 21, 2021

\section{Keywords:}

Knowledge/Experience sharing

Organizational learning,

Organizational memory,

Hotel establishments,

Scale development.

\section{A B S T R A C T}

The purpose of this study is to develop a valid and reliable scale related to knowledge/experience sharing, which plays an important role in the development of organizational memory and organizational learning in hotel businesses. The consistent integrity of 30 statements covering experience sharing motives, experience sharing channels and types of shared experiences was evaluated over data obtained from 333 employees within the years 2015-2016. Content validity of the scale was evaluated through expert opinions, construct validity were evaluated using Exploratory Factor Analysis and Confirmatory Factor Analysis. In determining reliability, Cronbach Alpha, Rho-A, Composite Reliability and Fornell-Larcker Criterion values were examined. As a result of the analyses, it has been determined that the building is a valid and reliable measurement tool.

\section{Giriş}

Otel işletmelerinin öğrenmesi üzerinde önemli sayıda çalışma yapılmıştır. $\mathrm{Bu}$ çalışmaların üzerinde durduğu önemli konulardan birisi öğrenmenin işletme kültürü ile çok yakından alakalı olduğu (Fiol ve Lyles 1985:7; Wishart, Elam ve Robey 1996:8) ve çalışanların da kültürün etkisiyle öğrenme eylemini gerçekleştirerek işletmenin sahip olduğu kümülatif bilgiye katkı sağladıklarıdır. $\mathrm{Bu}$ anlamda çalışanlar birer öğrenme aracısı konumundadırlar ve onların öğrenmesi işletmenin öğrenmesi anlamına da gelmektedir (Marsick ve Watkins, 2003:135; Yeo 2005:370). Çalışanların öğrenmesinin ise farklı kaynakları vardır. Pazarı takip etme, formal eğitim, kişisel gelişim çabaları vb. yanında çalışanların birbiri ile yaptıkları paylaşımlar da önemli bir öğrenme yolu olarak ele alınmaktadır (Avcı, Kılınç ve Okumuş, 2010:98; Fiol ve Lyles, 1985:15; Argyris, 1976:369). Bu yaklaşıma göre, işletmede -özelde

\footnotetext{
* Sorumlu yazar/Corresponding author. e-posta: melihkabadayi@outlook.com
} 
otel işletmelerinde- çalıșanların birbirileri ile etkin paylaşımları, birbirlerine kişisel deneyimlerini ve bilgi birikimlerini aktarmaları işletmenin bilgi yekûnuna katkı yapacak ve öğrenmeyi en üst seviyeye çıkaracaktır (Kocoğlu, İmamoğlu ve İnce, 2011:75). Diğer yandan, bazı araştırmacılara göre ise işletmede örgütsel öğrenme süreci bilginin elde edilmesi, işletme içine yayılması ve ortak sonuçlara ulaşılması aşamalarından oluşmaktadır (Marsick ve Watkins, 2003:135; Gomez, Lorente ve Cabrera, 2005:716). Bu yaklaşım da, çalı̧sanların birbirlerine deneyim aktarmasının bilginin işletme içine yayılarak tüm birimlerce yorumlanması, bir araya getirilip ele alınmasıly dış çevredeki değişime yönelik ortak, tutarlı ve stratejik eylemelere ulaştıracak şekilde kullanılması anlamına geldiğini vurgulamaktadır. $\mathrm{Bu}$ bağlamda çalışanların birbirleriyle bilgi ve deneyim paylaşımları öğrenme adına kritik bir süreçtir.

Örgütsel öğrenme sürecine dikkat çeken çalışmalarda sürecin önemli bir halkası olarak ele alınan örgüt hafizası oluşumu ve geliştirilmesinin de, çalışanların deneyim ve bilgi paylaşımı ile çok yakın ilgisi vardır (Kocoğlu vd., 2011:75). Zira, işletme içinde paylaşılan bilgi hem kültürel kalıplara yansımakta hem de kayıt merkezlerinde kayda dönüşmektedir (Yakut, 2016:248). Stein (1995:27), örgütsel belleğin örgütsel öğrenme için, öğrenmenin de bellek için gerekli olduğunu, öğrenilen bilgilerin örgütsel belleğe kazandırılması gerektiğini vurgulamaktadır. İşletme içinde örgütsel belleğe kaydedilecek bilgiler çoğu zaman paylaşım kanallarına sokularak dijital kayda girmektedir. Her bir çalışanın öğrendiği verinin işletme belleğine aktarılması, öğrenmeyi kalıcı hale getirmekte ve kurumsallaştırmaktadır (Örtenblad, 2004:133). Öyleyse çalışanların birbirinden öğrenmesi olarak görebileceğimiz bilgi ve deneyim paylaşımı aynı zamanda örgüt belleğini geliştiren önemli bir süreçtir. Dolayısıyla, literatürün dikkat çektiği ve örgütün öğrenmesi kapsamındaki bütün yap1 ve süreçlerin verimliliği çalışanların deneyim ve bilgi paylaşımının verimliliği ile yakından ilgilidir. Örgütsel öğrenme bahsedilen yapı ve süreçlerden oluşan bir sistem olarak görülebilir.

Belirtilen önemine karşın örgütsel öğrenme literatürünün, deneyim/bilgi paylaşım sürecine yeterince odaklanmadığ 1 görülmektedir. İşletmelerin verimliliği ve/veya performansına etkisi bağlamında öğrenmeyi ele alan birçok çalışma deneyim paylaşımının olup olmadığını kategorik veya aralıklı düzeyde ölçen ifadelerin oylanmasına bağlı olarak yüzeysel değerlendirmelerle yetinmiştir. Deneyim paylaşımını bir süreç olarak ele alan ve paylaşımın nesnesi, yolu ve içeriğine derinlemesine nüfuz edebilen bir literatürün eksikliği dikkat çekicidir. Bu çalışmada, örgütsel öğrenme sisteminin bir parçası olarak çalışanların birbirleriyle bilgi/deneyim paylaşması konusu; paylaşımın nedeni (hangi motivasyonla yapıldığı-amaç), paylaşımın nasıl olduğu (hangi kanallardan paylaşıldığı-yol) ve paylaşılanın ne olduğu (hangi tür deneyimlerin paylaşıldığıiçerik) üzerinden analiz edilmekte ve bu üç boyutun verimliliğini ölçecek bir ölçek geliştirilmektedir.

\section{Literatür İncelemesi}

\section{1. Örgütsel Öğrenme}

Örgütlerin bütünsel bir varlık olarak öğrenmeye duydukları ihtiyaç, küreselleşme akımıyla daha belirgin bir hale gelmiştir ve örgütsel öğrenme sürdürülebilir rekabet avantaj1 yaratmanın bir gereği olarak kabul edilmiştir (Khandekar, Sharma, 2006: 683). Bunun yanında örgütlerin öğrenmesi sürecinin neleri kapsadığı ve öğrenme olgusunun genel çerçevesinin çizilmesi konusunda alanyazında büyük farklıl1klar bulunmaktadır (Robey, Boudreau ve Rose, 2000:130; Fiol ve Lyles, 1985:9). İdeal bir örgüt şekli oluşturmayı veya öğrenmeyi içselleştirebilmiş bir örgüt durumunu ifade eden öğrenen örgüt kavramına karşllık örgütsel öğrenme, örgütün öğrenme sürecini ve bilgiye ulaşma yollarını vurgulamaktadır (Easterby-Smith, 1997:1086; Türkay, 2007:16-17; Yeo, 2005:369).

Örgütsel öğrenme olgusuna ilişkin alanyazın, March ve Simon'un (1958) çalışmalarıyla ortaya çıkmaya başlamıştır. Cyert ve March (1963) ve Cangelose ve Diil (1965) gibi araştırmacılar da örgütsel öğrenme olgusunu ele alan öncü araştırmacılardır. Cyert ve March (1963) örgütsel öğrenme kavramını psikolojik açıdan irdelerlerken, Nelson ve Winter (1982) ile Levitt ve March (1988) sosyolojik, Cangelosi ve Diil (1965), Senge (1990) ve Huber (1991) gibi araştırmacılar ise örgütsel teori yaklaşımıyla incelemişlerdir. Bu bağlamda kavrama ilişkin tanımlamalar da odaklanılan hususa göre değişkenlik göstermektedir. Örgütsel öğrenme, Dibella, Nevis ve Gould'a (1996:363) göre, bir örgüt içerisindeki deneyime bağlı olarak performansı sürdürme veya geliştirme kapasitesi, Kocoğlu, İmamoğlu ve İnce'ye (2011:74) göre örgütün problem çözme kapasitesini arttırmak için yeni bilgilerin edinilmesi, yorumlanması, saklanması ve uygulanmasi, Fiol ve Lyles'e (1985:4) göre ise, daha nitelikli bilgiler ve yaklaşımlarla eylemleri geliştirme sürecidir.

Örgütsel öğrenme otel işletmelerinde çalışanlar ve işletmeler için bazı değerli kazanımlar doğurmaktadır. Bilgiye rahat erişebilen ve öğrenme süreci sonunda bilgiyi uygulamaya geçirebilen çalışanların etkinliği ve iş tatmini yükselmektedir. Buna bağlı olarak bireylerin örgütsel bağlılığı ve örgüt lehine davranışlarda bulunma olasılıkları yükselmektedir. Böylece turizm endüstrisinin en büyük sorunlarından biri olan işgören devir hızı düşmekte ve işletme verimliliği gelişmektedir. Otel işletmelerinin yeniliklerle başa çıkabilmelerini, müşteri memnuniyetini yükseltmelerini, bunun sonucunda da rekabet üstünlügüu elde etmelerini mümkün kılmaktadır (Yang 2004:421; Avc1 ve Küçükusta, 2009:34).

Turizm literatürü incelendiğinde, örgütsel öğrenme ile ilgili çalışmalarının genellikle kriz yönetimi (Çiftçi, Küçükaltan ve Menteş, 2017), örgüt iklimi (Subramaiam, 2005; Gjelsvik, 2002), örgütsel performans (Avc1, 2005; Özdemir, 2006), örgütsel değişim (Chiang, 2010) ve örgütsel sessizlik (Tuna, Çelen ve Gök, 2019) gibi konulara odaklı olduğu görülmektedir. Bazı konular ise daha kısıtlı düzeyde ele alınmıştır. Avcı ve arkadaşları (2010) otel işletmelerinde öğrenme düzeyleri arasındaki ilişkiyi, Yang (2004) örgütsel öğrenme uygulamalarının müşteri memnuniyetine olan etkisini, Türkay (2007) pazara dayalı örgütsel öğrenme ve pazarlama performansına olan etkilerini, Magnini ve Honetcutt (2003) örgütsel öğrenmede yönetici faktörünü 
incelemişlerdir. Olgunun farklı yönlerinin daha fazla irdelenmesi turizm endüstrisine önemli katkılar sağlayacaktır.

\subsection{Bilgi Paylaşımı}

Bilgi, işletmeler arasındaki rekabetin yükselmesi, değişimin hızlanması ve bilgi teknolojileri kullanımındaki yayılmaya bağlı olarak, örgütler için en değerli varlık olmuştur. Benzersiz, kıt ve taklit edilmesi zor bir değer olarak, potansiyel bir rekabet avantajı kaynağıdır. İşletmelerin üretmiş oldukları malların ve/veya hizmetlerin kaynağını oluşturmaktadır. Ürün çeşitliliğinin hızla arttı̆ğ günümüz koşullarında bilgi, gün geçtikçe daha kısa ömürlü hale gelmektedir. İşletmelerin yakın geçmişte kendilerine rekabet avantaj1 sağlayan bilgileri, bugün için eskimiş olmakta ve eski değerini kaybetmesi dolayısıyla işletme rekabet avantajını yitirmektedir. Bilginin işletmeler için taşımış olduğu bu değer, araştırmacıları bu olgu üzerine çalışmaya sevk etmiş̧tir. Gerçekleştirilen araştırmalarda bilgi paylaşımı ile; kişilik özellikleri (Matzler, Renzl, Müller, Herting ve Mooradian, 2008), bilgi teknolojileri (Sharratt ve Usoro, 2003), örgüt kültürü (Gurteen, 1999; Ford ve Chan, 2003; Uludağ, Aktaş ve Özgit, 2019) ve ödül sistemleri (Bartol ve Srivastava, 2002) gibi konuların ilişkisine yoğunlaşıldığı görülmektedir.

Bilgi, deneyim ya da uygulama ile elde edilen, kazanılan olgu, uygulama ve tecrübe olarak kendini gösteren, bireyler ile işletmelerin faaliyetlerini verimli bir şekilde gerçekleştirmeleri için gerekli olan nitelik olarak tanımlanabilir (Erat, 2020:126). Bilgi yüksek değere sahip enformasyondur ve kullanılmadığında herhangi bir değer taşımamaktadır (Karavardar, 2012:143). Değer yaratmanın en güçlü silahı haline gelen bilgi, paylaşıldıkça daha çok değer üretmektedir. Geçmişte "bilgi güçtür" paradigması hakimken, bugün "bilgi paylaşımı güçtür" yaklaşımı geçerlilik kazanmıştır (Gurteen 1999:3). Bilgi paylaşımı, sahip olunan bilgiyi organizasyondaki diğer bireylere ulaştırma eylemidir. Bireyin deneyimini diğer bireyler tarafından anlaşılabilecek, özümsenebilecek ve kullanılabilecek bir forma dönüştürdüğü süreçtir (Ipe, 2003:341). Diğer bir ifade ile, bilginin bir bireyden, ekipten veya örgütten, diğer birey, ekip veya örgüte aktarılmasıdır (Sinkula, Baker ve Noordewier, 1997:306; Sharratt ve Usoro, 2003:190). Bilgi paylaşımında temel hedef, bireylerin bilgi ve deneyimlerini örgütsel verimi geliştirmek için örgütsel kaynaklara dâhil etmektir (Yang ve Wan, 2004:595). Çünkü örgütsel hedeflere ancak kişisel bilgi ve deneyimlerin paylaşılması ve iş süreçlerine kazandırılmasıyla ulaşılabilmektedir (Uludağ, Aktaş ve Özgit, 2019:161). Fikirlerin ürüne dönüştürülmesi, yenilik oluşturulması bilginin paylaşılması ile mümkündür. Cohen ve Levinthal (1990:133), farklı bilgilere sahip bireyler arasındaki etkileşimlerin, örgütteki herhangi bir bireyin başarabileceğinin çok ötesinde yenilik yaratabildiğini ifade etmektedirler. $\mathrm{Bu}$ bağlamda bilgiyi kişiden/birimden diğerine aktarma yeteneğinin, örgütsel performansa önemli katkı sağladığı söylenebilmektedir (Matzler vd., 2008:302).

Bir örgütte, kaynağından elde edilen bilgi ile yeni fikir/ürün üretebilmek, bilginin temel hareket ettiricileri olan çalışanlara bağlı bir süreçtir (Bartol ve Srivastava, 2002:64). Bu sebeple çalışanlar bir şirketin entelektüel sermayesi ve aynı zamanda sürdürülebilir gelişimi için kilit bir faktördür (Carneiro, 2000:90). Çalışanlar, resmi (formal/biçimsel) ya da gayri resmi (informal/biçimsel olmayan) paylaşımları sonucunda yeni fikir/ürün oluşumuna katkı sunmaktadırlar. Söz konusu resmi firsatlar arasında eğitim programları, yapılandırılmış çalışma ekipleri ve bilgi paylaşımını kolaylaştıran teknolojik sistemler bulunur. Gayri resmi firsatlar ise, öğrenmeyi ve bilgi paylaşımını kolaylaştıran kişisel ilişkileri ve sosyal ağları içerir (Brown ve Duguid, 1991:50; Nahapiet ve Ghoshal, 1998:244). Bilginin formal kanallardan daha fazla informal yollarla paylaşıldığı ve buna bağlı olarak sürecin önemli ölçüde çalışma ortamının kültürüyle ilişkili olduğu bilinmektedir (Ipe, 2003:355). Çalışanların ve örgütlerin bilgi paylaşım kültürleri ise, büyük ölçüde ulusal kültürden, örgüt yapısından ve yönetim tarzından etkilenmektedir (Ford ve Chan, 2003:11 Sveiby, 2007:1639). Bilgi paylaşımına kültürel ve kişisel unsurlardan hangilerinin ne oranda etki ettiğinin belirlenmesi önem arz etmektedir.

Bilgi güçtür ve bu güç paylaşıldıkça artar. Ancak bilgi paylaşımının önünde, genel olarak bilginin kendi doğasından, bireylerden ve örgütlerden kaynaklanan engeller mevcuttur. Bilginin doğasından kaynaklanan engel, bilginin ifade edilebilme biçimine göre açık ve örtülü olarak iki boyuttan oluşmasıdır (Bartol ve Srivastava, 2002:65; Ipe, 2003:344). Örtülü bilginin kolayca kodlanamaması ve genel olarak bilgiye sahip olan kişiye bağımlı olması, örgütlerde bilginin etkili bir şekilde paylaşılmasının önünde doğal bir engeldir (Ipe, 2003:344). Açık bilgi ise, yazılı veya sözlü olarak ifade edilebilen, kolayca paylaşılabilen bir yapıya sahiptir. (Matzler vd., 2008:303). Bireysel engeller, işgörenlerin deneyim, tecrübe ve motivasyon kapasitelerine bağlıdır. Örgütsel engeller ise, yapı, süreçler, kültür ve iletişim ile ilgilidir (Karavardar, 2012:143). Sveiby (2007:1636), örgütlerde bilgi paylaşımını engelleyen en önemli iki konunun, yönetici tutumları ve sistem oluşturucu bilgi eksikliği olduğunu belirtmektedir. Aktif bilgi paylaşımını teşvik etmeyen ilgisiz yöneticilerin, astların bilgi paylaşımını engellediğini savunmaktadır ve bu durumun çalışanları iş ortamında bilgiyi paylaşmaya daha az istekli hale getirdiğini öne sürmektedir. Diğer bir konu ise, örgütsel bilginin önemli bir kısmının bireyler düzeyinde kontrol edilmesidir (Jarvenpaa ve Staples, 2001:152). Bu durum bir çalışanın örgütten ayrılması halinde, bilgilerin de o kişi ile birlikte örgütten ayrılması gibi olumsuz bir sonucu doğurmaktadır (İmamoğlu, Kayış ve İnce, 2018:98). French ve Raven (1959:156), bilgiyi (uzmanlığı) paylaşmanın bireysel gücün erozyona uğramasına yol açabilecek bir güç kaynağı olarak tanımlamışlar ve bir bireyin başkalarıyla paylaşma konusundaki isteksizliğini bu nedene bağlı olarak açıklamışlardır. Szulanski (1996:31) ise bir kişinin bilgiyi paylaşma konusundaki isteksizliğini; bilginin sahipliğinden kaynaklanan üstünlüğü kaybetme korkusu, yeterince ödüllendirilmeme algısı, yeterli zaman olmaması ve bireyin transferi gerçekleştirmesi için gereken kaynakların bulunmaması gibi nedenlere dayandırmıştır. Dolayısıyla insanların güçlü kişisel motivasyonları ve paylaşımı teşvik eden bir örgütsel kültür olmadan, bilgi paylaşmaları pek olası değildir. Yöneticilerin iç ve/veya dış motivasyon unsurları aracilığıyla, çalışanları bilgi/deneyim paylaşımında bulunmaya motive etmeleri gerekmektedir. 


\subsection{Otel İşletmelerinde Bilgi/Deneyim Paylaşımının Öğrenme ve Hafıza Süreçleri ile İlişkisi}

Otel işletmelerinin sunmuş oldukları ürün, farklı mal ve hizmetlerin bileşiminden oluşmaktadır ve bu durum, ürün üretiminde ve sunumunda birtakım zorluklara neden olmaktadır. Çalışanlar söz konusu süreçlerde gerek kendi aralarında, gerekse de müşterilerle sıklıkla iletişim kurmak durumundadırlar. İşletmelerin başarılı olabilmeleri, büyük ölçüde bu süreçlerdeki iletişimin ve koordinasyonun gücüne bağlıdır. Dolayısıyla örgüt içerisindeki bilgi paylaşımının verimliliği işletmelerin başarılı olabilmelerinde büyük önem taşımaktadır.

Otel işletmeleri dinamik ve rekabetçi bir çevrede, değişen beklentilere karşılık verebilmek için yeni ürünler sunmak durumunda kalmaktadırlar (Liu, 2017:69). Böyle bir ortamda potansiyel misafirleri işletmeye çekebilmek, müşteri memnuniyeti ve bağlılığını sağlamak farklı ürün sunumuyla kolaylaşabilmektedir. Zira turistler, daha önce deneyimlemediği farklı ve eşsiz deneyimler aramaya yönelmişlerdir ( $\mathrm{Hu}$, Horng ve Sun, 2009:41). Bu nedenle son yıllarda önemli bir yönetsel yaklaşım olan bilgi paylaşımı olgusu üzerinde önemle durulmaktadır. Çünkü işletme içerisinde etkili bilgi paylaşımı, mevcut iş süreçlerinin verimliliğinin yanı sıra, yeni ürün geliştirilmesi noktasında da oldukça önemli bir role sahiptir (Ayazlar, 2012; Kim ve Lee, 2013). Bunun için otel yöneticileri işletme içerisinde bilgi paylaşımını kolaylaştıran ve geliştiren bir yaklaşıma sahip olmalıdırlar. Zira bilgi paylaşımının artması için, yöneticilerin destekleyici tutum ve davranışlarda bulunmaları, ödüllendirmelerin olması, inovasyona teşvik eden bir kültürün geliştirilmesi ve sosyal faktörlerin iyileştirilmesi elzemdir (Tiedemann, Van Birgele ve Semeijn, 2009:22; Chen ve Cheng, 2012:468; Kim ve Lee, 2012:2078). Ayrica duygusal zekanın, otellerde farklı kültürlerden bireylerin bir arada bulunmaları neticesinde görülen paylaşım sorunlarını ortadan kaldırma noktasında önemli potansiyele sahip olduğu bilinmektedir (Magnini, 2008:254).

Bilginin elde edilmesi ve personelin eğitilmesi işletmeler için zaman bakımından ve maddi olarak oldukça maliyetlidir. $\mathrm{Bu}$ nedenle işletmeler sahip oldukları bilgi kaynaklarını korumaya çaba göstermelidirler. Bilginin korunabilmesi ise bir anlamda işgücünün sürekliliğine bağlıdır. Ancak otel işletmelerinde personel devir oranının oldukça yüksek olması, mevcut bilginin sağlamış olduğu imkânların korunmasını zorlaştırmaktadır. $\mathrm{Bu}$ durumu önleyebilmek için, bilginin personele ve bilgi sistemlerine yayılması gerekmektedir. Örneğin bir çalışanın otel odasını daha hızlı temizlemek için keşfetmiş olduğu bir iş sıralamasını veya bir ön büro çalışanının uygulamakta olduğu bir tekniği diğer çalışanlarla paylaşması, verimlilik artışı sağlayacaktır. Aksi takdirde o kişilerin işletmeden ayrılmaları durumunda ilave işgücü/zaman/kaynak ihtiyacı ortaya çıkmaktadır.

Otellerde bilgi paylaşımı konusunda, bazı işletmelerin oldukça değerli uygulamaları mevcuttur. Örneğin Marriott, misafir memnuniyetini sağlamak adına, çalışanların elde etmiş olduğu verileri işletme hafızasında saklamak için bir sistem oluşturmuştur. Şirket ayrıca bilgi paylaşanlar için bir ödül sistemi tasarlayarak paylaşımı teşvik etmektedir. Ritz Carlton ise, misafirlerinin özel ilgi ve isteklerini öğrenip, bilgi havuzuna kaydetmektedir. Böylelikle aynı misafirler otele yeniden geldiklerinde, kişiselleştirilmiş ilgi gösterilerek misafir memnuniyetinin sağlanması hedeflenmektedir. Bununla birlikte, bilgi paylaşımı yalnızca müşteriler ile sınırlı değildir. Rakipler ve tedarikçiler başta olmak üzere, çeşitli paydaşlar ile ilgili bilgiler de siteme kaydedilmekte ve personel ile paylaşılmaktadır (Yang ve Wan, 2004:594). Bu uygulamalar bilgi paylaşımı ve örgütsel hafızayı güçlendirme noktasında iyi birer örnektir.

\section{Yöntem}

\section{1. Ölçeğin Maddelerinin Oluşturulması}

Ölçek geliştirmenin ilk aşamasında, konu ile ilgili literatür taraması yapılmıştır. Bilgi paylaşımı ile ilgili mevcut ölçekler ve otel işletmelerindeki bilgi paylaşım sürecine ilişkin çalışmaların vurgulamış oldukları unsurlar incelenmiştir. Nihayetinde paylaşım motivasyonu, kanalı ve paylaşılan bilginin içeriğgi gözetilerek yargı cümleleri oluşturulmuştur.

İnsanların iş ortamında diğerleri ile paylaşımlarda bulunması onların kişisel yönelimleri, duygu ve tutumları ile yakından ilintilidir. İşletmede bilgi akışında motivasyon (Kim ve Lee, 2013) ve kişilerarası ilişkilerin yoğunluğu (Magnini, 2008) kritik unsurlardır. Hangi tutumların bilgi paylaşımı noktasında önemli olacağı ve paylaşıma esas tutumları kapsayarak paylaşımın motivasyonel yönüne ilişkin geniş bir açıklayıcılık ortaya koyacağına karar verebilmek için literatürde dikkat çekilen boyutlara odaklanılmıştır.

Aidiyet hissinin çalışanların bilgi paylaşımı için motive edici bir faktör olduğu tespit edilmektedir (Ardichvili, 2008; Han, Chiang ve Chang, 2010). Bu kapsamda çalışanların diğerleri ile paylaştıkları güven ortamının bilgi paylaşımını artırdığı (Hsu ve Chang, 2014; Magnini, 2008), aidiyetin altruistik bir bağlılık yaratmasına (Han, Chiang ve Chang, 2010) da bağlı olarak diğerlerinin başarısı ve bölümün başarısının da bu aidiyet kapsamında değerlendirilerek bilgi paylaşımına etkisi olacağı düşünülebilir. Diğer yandan, insanların hedef yönelimliliklerinin bilgi paylaşımına etki edeceği Swift, Balkin ve Matusik (2010) tarafindan belirtilmektedir. Dolayısıyla bilgi paylaşarak daha başarılı olacaksa, terfi alacak ve daha fazla kazanacaksa, paylaşımda bulunma durumunun artacağını düşünmek gerekir (Kwok ve Gao, 2005). İnsanlar statü ve itibar için elektronik platformlarda bilgi paylaşımlarında bulunmaktadırlar (Chiu vd., 2011). $\mathrm{Bu}$ anlamda performans ve/veya başarı güdüsünün bilgi paylaşımı için önemli bir motivasyon olduğu söylenebilir. Literatürden hareketle, deneyim paylaşım güdüsünün farklı göstergelerini yansitan 25 madde oluşturulmuştur.

Bilgi paylaşım kanalları kapsamında informal ve formal kanallardan bahsedilmektedir (Kwok ve Gao, 2005). İşletmelerde her iki kanaldan da bilgi paylaşılmaktadır. Paylaşılan bilginin yazılı veya sözlü olması ise diğer önemli bir ayrımdır. Zira otellerde çoğu personel hareketli süreçlerde çalışmaktadır ve yazılı kanalları kullanma konusunda kısıtları söz konusu olabilir. Ayrıca paylaşımların hangisi formal hangisi informal sorusu çalışanlarca değerlendirilmesi zor ve hatta gereksiz görülebilir. İşletmelerde yüz yüze iletişim, telefonla, e- 
posta ile ve web teknolojileri kullanılarak iletişim gerçekleşmektedir (Snyder ve Lee-Partridge, 2009). Otellerde paket programlar ve otel veri tabanları üzerinden iletişimi de buna eklemek gerekir (Türkay, 2011). Yeni tarz ve teknoloji yoğun çalışma alanlarında daha çeşitli paylaşım kanallarının kullanıldığı, yüz yüze iletişimin yerini e-posta, telefon, video konferans vb. kanalların aldığ görülmektedir (Karavardar, 2012; de Kok, Bellefroid ve Helms, 2013). Paylaşım kanalı ile ilgili 6 madde oluşturulmuştur. Bu maddeler, işletmelerde mevcut iletişim kanallarının ifade edilmesi şeklinde olduğu için olası kanallarla sınırlı tutulmuş, kişisel ve işle ilgili olmayan iletişimlere de olanak sunduğu için sosyal medya dâhil edilmemiştir.

Paylaşımın içeriği konusundaki yargı cümleleri yine literatürden hareketle oluşturulmuştur. İşletme çalışanlarının bir araya geldikleri platformlarda işletmelerinin teknik sorunları/konuları üzerine bilgi alışverişi yaptıkları görülmektedir (Dawes, 1996; Altenburg, 1999). Bu paylaşımlar deneyimleri ve geçmişte çalışılan işletmelerin uygulama ve politikalarını da kapsamaktadır. Turizm gibi işgören devir oranının yüksek olduğu bir alanda çalışanların, farklı işletmelerde görev yapmış olma olasılıkları yüksektir ve bu durumda paylaşımlarının da mevcut işletme ortamından farklılıklar arz etmesine de bağlı olarak- önceki işletme uygulamalarına referanslar içermesi oldukça doğaldır. Bu nedenle, paylaşımın içeriğine dair ifadeler; geçmişte çalışılan işletmelerde yaşanan sorunlar, geçmiş müşteri deneyimleri, geçmişte çalışılan işletmelerin politikaları vb. geçmiş deneyimlerin yanında, işle ilgili yeni fikirler, işletme politikaları gibi uygulamaları da kapsamaktadır. Bu kapsamda 13 madde oluşturulmuştur.

Oluşturulan maddelerin anlaşılırlığını artırmak amacıyla farklı alanlarda eğitim gören 5 öğrenci ve 5 otel çalışanına ön deneme uygulaması gerçekleştirilmiştir. Kişilerden maddeleri sesli okumaları/doldurma istenmiş, böylelikle ifadelerin anlaşılırlığı belirlenmiş ve anlaşılmayan bazı ifadeler yeniden düzeltilerek veri toplama aracına son şekli verilmiştir.

\subsection{Verilerin Toplanmas1}

Çalışmada nicel araştırma yöntemlerinden anket tekniği kullanılmıştır. Veri toplama formu dört bölüm olarak şekillendirilmiştir. Formun ilk kısmında deneyim paylaşım güdüleri ile ilgili ifadelere yer verilmiştir. İkinci kısımda deneyim paylaşımında kullanılan kanallara ilişkin ifadeler bulunmaktadır. Üçüncü bölümde paylaşılan deneyim türleri ile ilgili ifadeler yer almaktadır. Dördüncü bölümde ise katılımcıların demografik özelliklerine ilişkin ifadeler bulunmaktadır. Deneyim paylaşım güdüleri ile ilgili ifadelerin değerlendirilmesinde "1-Kesinlikle Katılmıyorum/5-Kesinlikle Katılıyorum” şeklindeki Likert tipi derecelendirme kullanılmıştır. Katılımcıların paylaşım kanalı ve deneyim türlerine ilişkin değerlendirmeleri ise "1Hiçbir zaman/5-Her zaman” şeklindeki Likert tipi ifadelerle ölçülmüştür. Veriler tesadüfi olmayan örnekleme tekniklerinden kolayda örnekleme tekniği kullanılarak, 2015-2016 yıllarında İstanbul ilinde faaliyette bulunan iki adet 4 yıldızlı ve 6 adet 5 yıldızlı 333 otel çalışanından elde edilmiştir.

\subsection{Verilerin Analizi}

Çalışmaya katılım gösteren 333 otel çalışanından elde edilen yanıtlar doğrultusunda ölçeğin geçerliği ve güvenirliği test edilmiştir. Ölçeğin geçerliğinin belirlenmesi amacıyla öncelikle Açıklayıcı Faktör Analizi (AFA) yapılmıştır. Ardından AFA sonucunda oluşan yapı, Doğrulayıcı Faktör Analizi (DFA) ile test edilmiştir. Ölçeğin güvenirliği ise Cronbach Alpha, Rho-A ve Composite Reliability ve Fornell-Larcker Criterion güvenilirlik katsayıları kullanılarak hesaplanmıştır.

\section{4. Çalışma Grubunun Demografik Özellikleri}

Araştırmaya katılan 333 kişinin 194'ü (\%58,3) erkek, 126 's1 $(\% 37,8)$ ise kadındır. Katılımcıların yarısından fazlası $(\% 55) 30$ yaş ve altı grupta yer almaktadır. Kişilerin \%24'ü 31-35, \%9,3'ü 36-40 yaş aralığında bulunmaktadır. Katılımcıların \%10,8'i ise 40 yaşının üzerindedir. Çalışanların \%8,4'ü ilköğretim, \%22,5'i lise, \%17,7'si önlisans, \%40'1 lisans ve \%3,6's1 ise lisansüstü düzeyde eğitime sahiptir. Çalışanların \%47,7'si yediden daha az kişiyle sıklıkla deneyim paylaşımında bulunmaktadır. Katılımciların \%30,9'u ön büro, \%26,7'si teknik servis, \%14,4'ü yiyecek-içecek, \%6,6'sı kat hizmetleri ve \%5,7'si ise mutfak bölümünde çalışmaktadır. Katılımcıların \%26,7'si mesleklerinde 5 yil veya daha fazla bir deneyime sahiptir. Diğer bireylerin \%15,9'u 1 yıldan az, \%13,8'si 1-2 y1l, 17,7'si 2-3 y1l, \%12,6's1 3-4 y1l, \%9'u ise 4-5 y1l aralığında değişen deneyime sahiptir.

\section{Bulgular}

\subsection{Açıklayıcı Faktör Analizi (AFA) ve Güvenirlik $(\alpha)$}

Ölçekte yer alan boyutlara ait güvenirlik ve geçerlilik analizlerine ilişkin SPSS verileri Tablo 2'de sunulmaktadır. Tüm boyutlara ait ifadelerin katılımcılar tarafından doğru algılanıp algılanmadığının belirlenmesi için gerçekleştirilen güvenilirlik analizi sonucunda, Cronbach Alpha değerlerinin (0,660-0,714) yeterli düzeyde olduğu (İslamoğlu, 2009) tespit edilmiştir. Ölçeğin yap1 geçerliğinin tespit edilmesinde ise Açıklayıcı Faktör Analizi kullanılmıştır. AFA'da ilk olarak verilerin faktör analizine uygun olup olmadığı değerlendirilmek amacıyla Kaiser-Meyer-Olkin (KMO) örneklem uygunluğu ve Bartlett Küresellik Testi değerlerinin anlamlılı̆̆ına bakılmıştır. KMO örneklem uygunluğu değerinin $(0,825)$ yeterli (Kalayc1, 2016) seviyede olduğu ve Bartlett Küresellik Testi sonucunun anlamlı (Ki-Kare=4521,955; $\mathrm{p}=0,000$ ) olduğu görülmüştür. $\mathrm{Bu}$ sonuçlara bağlı olarak, verilerin faktör analizi için uygun olduğu ve faktör analizi sonucunun geçerli olduğu söylenebilmektedir. Verilerin analizinde Temel Bileşenler Yöntemi ve "Direct Oblimin" rotasyonu kullanılmıştır. Başlangıç özdeğerleri 1'in (Eigenvalue> 1) üzerinde bulunan boyutlar değerlendirmeye alınmıştır. Faktör yükleri iki veya daha fazla boyutta birbirine yakın olan ifadeler, korelasyonunu düşük olan ifadeler ve birden fazla boyutta 0,500'ün üzerinde değere sahip olan ifadeler analizden çıkarılmıştır. Analiz sonucunda 28 olumlu maddeden ve 8 boyuttan oluşan bir yap1 ortaya çıkmıştır. Faktör yüklerinin 0,582 ile 0,938 aralığında değiştiği ve bu değerlerin makul sınırlar içerisinde yer aldığ1 görülmüştür. Elde edilen yapının, varyansın \% 75,14'ünü açıkladığı tespit edilmiştir. 
Tablo 2: AFA ve Güvenirlik ( $\alpha$ ) Sonuçları

\begin{tabular}{|c|c|c|c|c|c|c|c|}
\hline & Faktörler & $\begin{array}{c}\text { Faktör } \\
\text { Yükü }\end{array}$ & $\mid \begin{array}{c}\text { Öz } \\
\text { Değer }\end{array}$ & \begin{tabular}{|c|} 
Açıklanan \\
Varyans \\
Yüzdesi \\
\end{tabular} & $\begin{array}{c}\text { Ort. } \\
(\overline{\mathbf{x}})\end{array}$ & $\begin{array}{c}\text { Std. } \\
\text { Sapma }\end{array}$ & $\begin{array}{c}\text { Alpha } \\
(\alpha)\end{array}$ \\
\hline \multirow{13}{*}{ 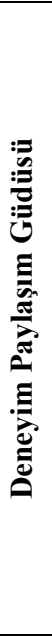 } & Aidiyet Güdüsü & & \multirow{4}{*}{3,658} & \multirow{4}{*}{13,065} & \multirow{4}{*}{4,05} & \multirow{4}{*}{,881 } & \multirow{4}{*}{,692 } \\
\hline & $\begin{array}{l}\text { İs arkadaşlarımın bana güvenmesini istediğim için onlarla deneyimlerimi } \\
\text { paylaşırım }\end{array}$ & ,758 & & & & & \\
\hline & $\begin{array}{l}\text { Iş arkadaşlarımın bilgilenmesi ve işini daha iyi yapması için onlarla } \\
\text { deneyimlerimi paylaşırım }\end{array}$ & ,834 & & & & & \\
\hline & $\begin{array}{l}\text { Bizim bölüm olarak daha başarılı olmamız için arkadaşlarımla deneyimlerimi } \\
\text { paylaşırım }\end{array}$ & ,788 & & & & & \\
\hline & Performans Güdüsü & & \multirow{4}{*}{1,397} & \multirow{4}{*}{4,989} & \multirow{4}{*}{3,31} & \multirow{4}{*}{1,09} & \multirow{4}{*}{699} \\
\hline & İşi iyi bildiğimi göstereceği için deneyimlerimi diğerlerine anlatırım & ,582 & & & & & \\
\hline & Bana terfi getireceği için deneyimlerimi paylaşırım & 887 & & & & & \\
\hline & Bana daha fazla ücret getireceği için deneyimlerimi paylaşırım & ,938 & & & & & \\
\hline & Örgütsel Güdü & & \multirow{5}{*}{1,207} & \multirow{5}{*}{4,312} & \multirow{5}{*}{3,96} & \multirow{5}{*}{,828 } & \multirow{5}{*}{,682 } \\
\hline & İşletmemin başarılı olmasını sağlayacağı için deneyimlerimi paylaşırım &, 702 & & & & & \\
\hline & $\begin{array}{l}\text { Müşterilere hak ettiği hizmeti sunabilmek adına deneyimlerimi } \\
\text { arkadaşlarımla paylaşırım }\end{array}$ & 627 & & & & & \\
\hline & Sıklıkla kendi bölümümdeki arkadaşlarımla fikir ve deneyimlerimi paylaşırım & , 846 & & & & & \\
\hline & Bütün işletmeden arkadaşlarımla fikir ve deneyimlerimi paylaşırım & ,743 & & & & & \\
\hline \multirow{8}{*}{ 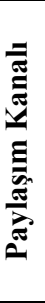 } & Yazılı Paylaşım & & \multirow{4}{*}{1,583} & \multirow{4}{*}{5,655} & \multirow{4}{*}{335} & \multirow{4}{*}{1,23} & \multirow{4}{*}{,714 } \\
\hline & Otelin kullandığı paket program-yazılım & ,928 & & & & & \\
\hline & Otelin internet sitesi-veri tabanı & 908 & & & & & \\
\hline & Yazılı olarak-bölümler arası yazılı mesajlar & 643 & & & & & \\
\hline & Sözlü Paylaşım & & \multirow{4}{*}{1,967} & \multirow{4}{*}{7,024} & \multirow{4}{*}{3,95} & \multirow{4}{*}{,841 } & \multirow{4}{*}{,696 } \\
\hline & Sözlü olarak ve iş esnasında-iș saatlerinde & 804 & & & & & \\
\hline & Sözlü olarak ve iş dışı zamanlarda & ,682 & & & & & \\
\hline & Sözlü olarak ve toplantılarda & ,700 & & & & & \\
\hline & Geçmiş sorunlar & & & & & & \\
\hline & İşle ilgili geçmişte yaşadığım sorunlar & ,935 & & & & 101 & \\
\hline & İşyerimle ilgili geçmişte yaşadığım sorunlar & ,893 & 1,259 & 4,498 & 3,54 & 1,01 & 696 \\
\hline & Geçmişte müşterilerle kurduğum ilişkiler & 562 & & & & & \\
\hline & Yeni fikirler & & & & & & \\
\hline$\stackrel{\Xi}{2}$ & İşle ilgili yeni fikirlerim & 657 & 2571 & 0.181 & 382 & 864 & 660 \\
\hline 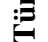 & İşle ilgili çevre işletmelerde gördüğüm uygulamalar &, 774 & $2,5 / 1$ & 9,181 & 3,82 & , & 660 \\
\hline$\Xi$ & İşletmemizin politikaları & ,768 & & & & & \\
\hline 俤 & İşletmemizdeki uygulamalar & ,788 & & & & & \\
\hline Е & Geçmiş deneyimler & & & & & & \\
\hline & İşletmemizde geçmişte yaşanmış ilginç olaylar & ,693 & & & & & \\
\hline & Geçmişte birlikte çalıştığım iş arkadaşlarım & ,853 & 7307 & 26 & 1353 & 014 & 670 \\
\hline & Geçmişte birlikte çalıştığım yöneticilerim & ,852 & 1,391 & 26,419 & 3,53 &, 914 & 6/9 \\
\hline & Geçmişte çalıştığım işletmelerin uygulamaları &, 725 & & & & & \\
\hline & Geçmiște çalıștığım işletmelerin politikaları & 781 & & & & & \\
\hline
\end{tabular}

\subsection{Doğrulayıcı Faktör Analizi (DFA)}

AFA sonucunda 28 ifade ve 8 faktör olarak şekillenen yapı, DFA aracılı̆̆ıyla test edilmiştir. DFA için ilk olarak LISREL programı kullanılmıştır. DFA daha önceden şekillenmiş ve sınırlandırılmış bir yapının, bir model olarak doğrulanıp doğrulanmadığının incelendiği bir tekniktir (Çokluk, Şekercioğlu ve Büyüköztürk, 2010). DFA'da X2/sd, RMSEA, SRMR, CFI, GFI, AGFI, IFI, RFI, RMR, NFI ve NNFI değerlerinin incelenmesi gerekmektedir. DFA sonuçlarının geçerli olabilmesi için bu değerler kabul edilebilir düzeyde olmalıdır. DFA sonuçlarının normal değerleri, kabul edilebilir değerleri ve çalışma ölçeğine ait değerler Tablo 3'te aktarılmaktadır.
DFA işlemi sonucu elde edilen yol diyagramına ise Şekil 1 'de yer verilmektedir. Diyagramda Ki-kare ve uyum değerlerini iyileştirmek amacıyla gerçekleștirilen modifikasyonlar da gösterilmektedir. "Performans güdüsü" faktöründeki madde 17 ve madde 18 'in; "yeni fikirler" faktöründeki madde 4, 5, 6 ve 7'nin ve "geçmiş deneyimler" faktöründeki madde $10,11,12$ ve 13 'ün hata varyansları ilişkilendirilmiştir. Yol diyagramı incelendiğinde, ilişkilendirilen maddelerin aynı faktörler içerisinde yer aldıkları ve aynı konuları/özellikleri ölçtükleri görülmektedir. 
Şekil 1. Bilgi/Deneyim Paylaşım Ölçeği’ne Ait Yol Diyagramı

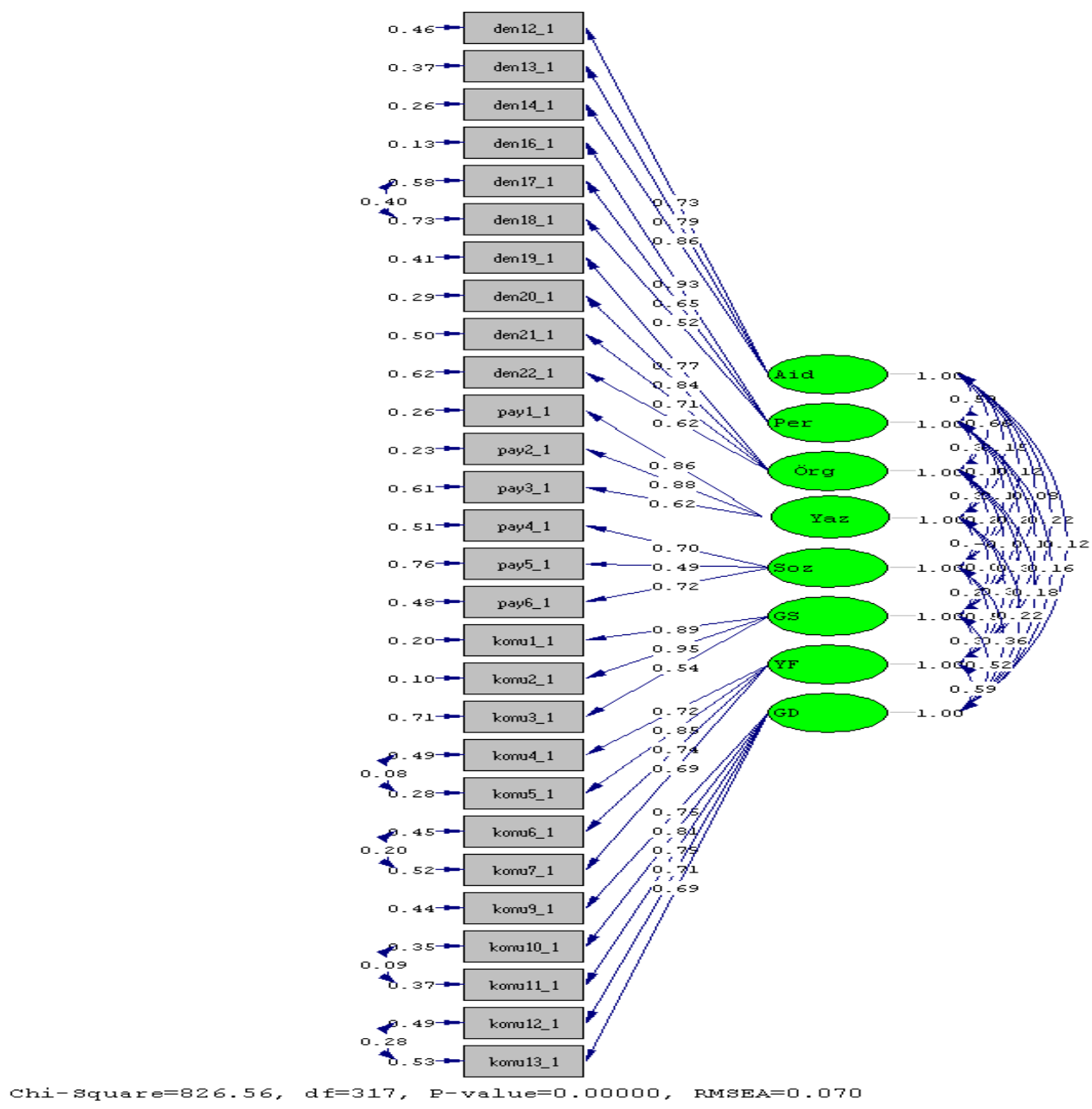

Ölçeğin AFA sonucundaki faktör yapısını desteklemek amaciyla gerçekleştirilen DFA sonucunda; $\mathrm{X} 2 / \mathrm{sd}=2,60$, RMSEA $=0,07$, SRMR $=0,079 \mathrm{CFI}=0,94, \mathrm{GFI}=0,85$, $\mathrm{AGFI}=0,81, \mathrm{NFI}=0,91$ ve $\mathrm{NNFI}=0,93, \mathrm{IFI}=0,94, \mathrm{RFI}=$ 0,90 ve $R M R=0,079$ olarak bulunmuştur. Uyum iyiliği istatistiklerinden SRMR ve RMSEA değerlerinin kabul edilebilir sınırlar dâhilinde olduğu görülmüştür. X2/sd, katsayısının 2,60 olması, model ile veriler arasında mükemmel bir uyumun bulunduğunu göstermektedir. Diğer uyum değerleri de kabul edilebilir değerlere sahiptir (Marsh ve Balla, 1992; Frias ve Dixon, 2005; Yaşlığlu, 2017).

Tablo 3: DFA modeli Uyum Değerleri

\begin{tabular}{llll}
\hline İndeks & Normal Değer & Kabul Edilebilir Değer & Bulunan Değer \\
$\mathrm{X}^{2}$ için p değeri & $\mathrm{p}>0,05$ & - & \\
$\mathrm{X}^{2}$ sd & $<2$ & $<5$ & 2,60 \\
$\mathrm{GFI}$ & $>0,95$ & $>0,85$ & 0,85 \\
$\mathrm{CFI}$ & $>0,95$ & $>0,90$ & 0,94 \\
NFI & $>0,95$ & $>0,90$ & 0,91 \\
NNFI & $>0,95$ & $>0,90$ & 0,93 \\
IFI & $>0,95$ & $>0,90$ & 0,94 \\
RFI & $>0,95$ & $>0,90$ & 0,90 \\
RMSEA & $<0,05$ & $<0,08$ & 0,07 \\
RMR & $<0,05$ & $<0,08$ & 0,079 \\
SRMR & $<0,05$ & $<0,08$ & 0,079 \\
\hline
\end{tabular}

DFA'ya ait faktör yüklerine, standart hata ve korelasyon $\left(\mathrm{R}^{2}\right)$ değerlerine Tablo $4^{\text {'te }}$ yer verilmektedir. Analiz sonucunda faktör yüklerinin 0,49 ile 0,95 arasında değiştiği, kabul edilebilir değerlere sahip oldukları ve istatistiksel olarak anlamlı oldukları tespit edilmiştir. İfadelerin $\mathrm{R}^{2}$ değerlerinin ise, 0,29 ile 0,90 arasında değiştiği

görülmüştür. Tüm bu değerler ölçeğin yeterli seviyede yap1 geçerliğine sahip olduğunu göstermektedir. 
Tablo 4: DFA Analizi Faktör Değerleri

\begin{tabular}{|c|c|c|c|}
\hline İfadeler & $\begin{array}{l}\text { Faktör } \\
\text { Yükleri } \\
\end{array}$ & $\begin{array}{c}\text { Standart } \\
\text { Hata }\end{array}$ & $\mathbf{R}^{\mathbf{2}}$ \\
\hline İş arkadaşlarımın bana güvenmesini istediğim için onlarla deneyimlerimi paylaşırım & 0,73 & 0,46 & 0,54 \\
\hline İş arkadaşlarımın bilgilenmesi ve işini daha iyi yapması için onlarla deneyimlerimi paylaşırım & 0,79 & 0,37 & 0,63 \\
\hline Bizim bölüm olarak daha başarılı olmamız için arkadaşlarımla deneyimlerimi paylaşırım & 0,86 & 0,26 & 0,74 \\
\hline İşi iyi bildiğimi göstereceği için deneyimlerimi diğerlerine anlatırım & 0,93 & 0,13 & 0,87 \\
\hline Bana terfi getireceği için deneyimlerimi paylaşırım & 0,65 & 0,58 & 0,42 \\
\hline Bana daha fazla ücret getireceği için deneyimlerimi paylaşırım & 0,52 & 0,73 & 0,27 \\
\hline İşletmemin başarılı olmasını sağlayacağı için deneyimlerimi paylaşırım & 0,77 & 0,41 & 0,59 \\
\hline Müşterilere hak ettiği hizmeti sunabilmek adına deneyimlerimi arkadaşlarımla paylaşırım & 0,84 & 0,29 & 0,71 \\
\hline Sıklıkla kendi bölümümdeki arkadaşlarımla fikir ve deneyimlerimi paylaşırım & 0,71 & 0,50 & 0,50 \\
\hline Bütün işletmeden arkadaşlarımla fikir ve deneyimlerimi paylaşırım & 0,62 & 0,62 & 0,38 \\
\hline Otelin kullandığı paket program-yazılım & 0,86 & 0,26 & 0,74 \\
\hline Otelin internet sitesi-veri taban1 & 0,88 & 0,23 & 0,77 \\
\hline Yazılı olarak-bölümler arası yazılı mesajlar & 0,62 & 0,61 & 0,39 \\
\hline Sözlü olarak ve iş esnasında-iş saatlerinde & 0,70 & 0,51 & 0,49 \\
\hline Sözlü olarak ve iş dışı zamanlarda & 0,49 & 0,76 & 0,24 \\
\hline Sözlü olarak ve toplantılarda & 0,72 & 0,48 & 0,52 \\
\hline İşle ilgili geçmişte yaşadığım sorunlar & 0,89 & 0,20 & 0,80 \\
\hline İşyerimle ilgili geçmişte yaşadığım sorunlar & 0,95 & 0,10 & 0,90 \\
\hline Geçmişte müşterilerle kurduğum ilişkiler & 0,54 & 0,71 & 0,29 \\
\hline İşle ilgili yeni fikirlerim & 0,72 & 0,49 & 0,51 \\
\hline İşle ilgili çevre işletmelerde gördüğüm uygulamalar & 0,85 & 0,28 & 0,72 \\
\hline İşletmemizin politikaları & 0,74 & 0,45 & 0,55 \\
\hline İşletmemizdeki uygulamalar & 0,69 & 0,52 & 0,48 \\
\hline İşletmemizde geçmişte yaşanmış ilginç olaylar & 0,75 & 0,44 & 0,56 \\
\hline Geçmişte birlikte çalıştığım iş arkadaşlarım & 0,81 & 0,35 & 0,65 \\
\hline Geçmişte birlikte çalıştı̆̆ım yöneticilerim & 0,79 & 0,37 & 0,63 \\
\hline Geçmişte çalıştığım işletmelerin uygulamaları & 0,71 & 0,49 & 0,51 \\
\hline Geçmişte çalıştı̆ı̆m işletmelerin politikaları & 0,69 & 0,53 & 0,47 \\
\hline
\end{tabular}

DFA sonucunda ölçekte yer alan boyutlar arasındaki korelasyon katsayıları Tablo 5'te sunulmuştur. Boyutlar arasındaki en yüksek ilişkinin aidiyet güdüsü ile örgütsel güdü $(0,66)$ arasında olduğu görülmüştür. Bununla birlikte yeni fikirler-geçmiş deneyimler $(0,59)$, geçmiş sorunlargeçmiş deneyimler $(0,50)$, sözlü paylaşım-yeni fikirler $(0,49)$, aidiyet güdüsü-performans güdüsü $(0,42)$ arasında da orta düzeyde ilişkilerin bulunduğu tespit edilmiştir.

Tablo 5: Korelasyon Katsayıları

\begin{tabular}{|c|c|c|c|c|c|c|c|}
\hline & Performans & Örgütsel & Yazılı & Sözlü & $\begin{array}{c}\text { Geçmiş } \\
\text { Sorun }\end{array}$ & Yeni Fikir & $\begin{array}{c}\text { Geçmiş } \\
\text { Deneyim }\end{array}$ \\
\hline Aidiyet & 0,42 & 0,66 & 0,15 & 0,12 & 0,08 & 0,24 & 0,15 \\
\hline Performans & & 0,38 & 0,15 & 0,14 & 0,20 & 0,24 & 0,17 \\
\hline Örgütsel & & & 0,30 & 0,21 & $-0,01$ & 0,38 & 0,20 \\
\hline Yazilı & & & & 0,34 & 0,08 & 0,35 & 0,24 \\
\hline Sözlü & & & & & 0,20 & 0,49 & 0,34 \\
\hline Geçmiş Sorun & & & & & & 0,29 & 0,50 \\
\hline Yeni Fikir & & & & & & & 0,59 \\
\hline
\end{tabular}

Araştırma boyutlarının güvenilirlik ve geçerlilik durumu ayrıca SmartPLS Programı ile test edilmiştir. Güvenilirlik; Cronbach's Alpha $(\alpha)$, Rho-A ve Komposit güvenilirlik testleri aracılığıyla her bir boyut için ayrı ayrı hesaplanmıştır (Tablo 6). Ulaşılan sonuçlar tüm katsayıların kabul edilebilir düzeyde olduğunu göstermektedir (Campbell ve Fiske, 1959; Carmines ve Zeller, 1979;
Nunnally ve Bernstein, 1994). Bu sonuçlara bağlı olarak her bir faktörün güvenilirlik koșulunu sağladığı söylenebilmektedir. Tüm boyutlara ait AVE değerlerinin de sosyal bilimler için istenilen $(>0,50)$ düzeyde olduğu ve faktörlerin yakınsak geçerlik koşulunun sağlandığı görülmüştür (Hair, vd., 2010).

Tablo 6: Güvenilirlik ve Geçerlilik Değerleri

\begin{tabular}{l|c|c|c|c}
\hline \multicolumn{1}{c|}{ Değişkenler } & Cronbach's Alpha & $\begin{array}{c}\text { Reliability Coefficient } \\
\text { (Rho_A) }\end{array}$ & $\begin{array}{c}\text { Composite } \\
\text { Reliability }\end{array}$ & AVE \\
\hline AİDG(1) &, 835 &, 840 &, 901 &, 752 \\
\hline PERG(2) &, 825 &, 844 &, 896 &, 742 \\
\hline PAYG(3) &, 828 &, 828 &, 886 &, 660 \\
\hline YAZ(4) &, 822 &, 826 &, 894 &, 739 \\
\hline SÖZ(5) &, 673 &, 698 &, 819 &, 602 \\
\hline GEÇS(6) &, 822 &, 819 &, 895 &, 740 \\
\hline YENF(7) &,, 857 &, 925 &, 900 &, 693 \\
\hline GEÇD(8) &, 879 &, 947 &, 905 &, 658 \\
\hline
\end{tabular}


Cronbach'ın Alpha katsayısının yanı sira, her bir boyutun güvenilirliği Fornell ve Larcker'in (1981) bileşik güvenilirlik ölçümü ile test edilmiştir. Fornell-Larcker Kriter katsayılarını gösteren Tablo 7'deki matriste koyu renk ile gösterilen değerler AVE'nin karekökünü göstermektedir. AVE katsayılarının kareköklerinin, her bir faktörün korelasyon değerinden daha büyük olması, yakınsak geçerliliğinin sağlandığını göstermektedir (Fornell ve Larcker, 1981). Fornell-Larcker Criterion değerlendirmesinde satır ve sütunlardaki değerlerin tümünün, koyu yazılı değerlerden daha küçük olması ve Heterotrait-Monotrait Ratio değerlerinin, 0 ile 1 arasında değer alması (Tablo 7), araştırma boyutları arasında ayrışma geçerliliğinin sağlandığını göstermektedir (Hair, Hult, Ringle \& Sarstedt, 2017; Hair, vd, 2017).

Tablo 7: Fornell-Larcker Criterion ve Heterotrait-Monotrait Ratio Değerleri

\begin{tabular}{|c|c|c|c|c|c|c|c|c|}
\hline \multicolumn{9}{|c|}{ Fornell-Larcker Criterion Değerleri } \\
\hline Değişkenler & 1 & 2 & 3 & 4 & 5 & 6 & 7 & 8 \\
\hline AİDG & 867 & & & & & & & \\
\hline PERG & ,433 & ,862 & & & & & & \\
\hline ÖRGG & ,523 & ,350 & ,812 & & & & & \\
\hline YAZ & 128 & 129 & 259 & ,860 & & & & \\
\hline SÖZ & 133 & 136 & 143 & ,302 & ,776 & & & \\
\hline GEÇS & 105 & 202 &, 350 & , 127 & 269 & ,860 & & \\
\hline YENF & 229 & 204 &, 346 &, 329 & 341 & 381 &, $\mathbf{8 3 2}$ & \\
\hline GEÇD & ,162 & 196 & ,205 & ,226 & ,269 & 477 &, 524 &, 811 \\
\hline \multicolumn{9}{|c|}{ Heterotrait-Monotrait Ratio Değerleri } \\
\hline Değișkenler & 1 & 2 & 3 & 4 & 5 & 6 & 7 & 8 \\
\hline
\end{tabular}

\begin{tabular}{lll}
\hline AİDG & $\mathbf{1}$ & $\mathbf{2}$ \\
PERG & .520 & \\
ÖRGG & .625 & .420 \\
YAZ & .153 & .152 \\
SÖZ & .172 & .188 \\
GEÇS & .127 & .245 \\
YENF & .245 & .216 \\
GEÇD & .153 & .198 \\
\hline
\end{tabular}

Araştırmanın veri setinde ortak yöntem varyansı (comon method variance) sorunu bulunup bulunmadiğı, VIF değerleri ile değerlendirilmiştir (Hair vd. 2014; Kock 2015). Analizler sonucunda VIF değerlerinin 1,2 ile 3,7 arasında değiştiği görülmüştür (Tablo:8). VIF değerlerinin 5 'in altında olması, değişkenler arasında doğrusallık

Tablo 8: VIF, Faktör Yükü, ve T Değerleri

\begin{tabular}{|c|c|c|c|}
\hline İfadeler & VIF & Faktör Yükü & t-Değeri \\
\hline İş arkadaşlarımın bana güvenmesini istediğim için onlarla deneyimlerimi paylaşırım & 1,725 & .851 & $17.241 * *$ \\
\hline İş arkadaşlarımın bilgilenmesi ve işini daha iyi yapması için onlarla deneyimlerimi paylaşırım & 2,101 & .862 & $26.697 * *$ \\
\hline Bizim bölüm olarak daha başarılı olmamız için arkadaşlarımla deneyimlerimi paylaşırım & 2,182 & .888 & $29.721 * *$ \\
\hline İşi iyi bildiğimi göstereceği için deneyimlerimi diğerlerine anlatırım & 1,578 & .798 & $16.875 * *$ \\
\hline Bana terfi getireceği için deneyimlerimi paylaşırım & 2,642 & .921 & $53.227 * *$ \\
\hline Bana daha fazla ücret getireceği için deneyimlerimi paylaşırım & 2,228 & .860 & $25.073 * *$ \\
\hline İşletmemin başarılı olmasını sağlayacağı için deneyimlerimi paylaşırım & 1,973 & .817 & $22.661 * *$ \\
\hline Müşterilere hak ettiği hizmeti sunabilmek adına deneyimlerimi arkadaşlarımla paylaşırım & 2,065 & .841 & $24.704 * *$ \\
\hline Sıklıkla kendi bölümümdeki arkadaşlarımla fikir ve deneyimlerimi paylaşırım & 1,849 & .817 & $2.174 * *$ \\
\hline Bütün işletmeden arkadaşlarımla fikir ve deneyimlerimi paylaşırım & 1,575 & .772 & $19.180 * *$ \\
\hline Otelin kullandığı paket program-yazılım & 2,515 & .879 & $24.366 * *$ \\
\hline Otelin internet sitesi-veri tabanı & 2,557 & .898 & $31.785 * *$ \\
\hline Yazılı olarak-bölümler arası yazılı mesajlar & 1,460 & .799 & $14.867 * *$ \\
\hline Sözlü olarak ve iş esnasında-iş saatlerinde & 1,400 & .843 & $3.982 * *$ \\
\hline Sözlü olarak ve iş dışı zamanlarda & 1,212 & .729 & $2.542 *$ \\
\hline Sözlü olarak ve toplantılarda & 1,400 & .751 & $4.153 * *$ \\
\hline İşle ilgili geçmişte yaşadığım sorunlar & 3,604 & .893 & $8.246 * *$ \\
\hline İşyerimle ilgili geçmişte yaşadığım sorunlar & 3,720 & .905 & $8.495 * *$ \\
\hline Geçmişte müşterilerle kurduğum ilişkiler & 1,344 & .777 & $6.664 * *$ \\
\hline İşle ilgili yeni fikirlerim & 1,915 & .724 & $12.218 * *$ \\
\hline İşle ilgili çevre işletmelerde gördüğüm uygulamalar & 2,568 & .835 & $21.622 * *$ \\
\hline İşletmemizin politikaları & 2,449 & .906 & $52.725 * *$ \\
\hline İşletmemizdeki uygulamalar & 2,195 & .855 & $29.279 * *$ \\
\hline İşletmemizde geçmişte yaşanmış ilginç olaylar & 1,918 & .665 & $7.490 * *$ \\
\hline Geçmişte birlikte çalıştığım iş arkadaşlarım & 2,776 & .788 & $10.246 * *$ \\
\hline Geçmişte birlikte çalıştığım yöneticilerim & 2,509 & .808 & $12.428 * *$ \\
\hline Geçmişte çalıştığım işletmelerin uygulamaları & 2,737 & .889 & $31.780 * *$ \\
\hline Geçmişte çalıştığım işletmelerin politikaları & 2,660 & .885 & $29.156 * *$ \\
\hline
\end{tabular}

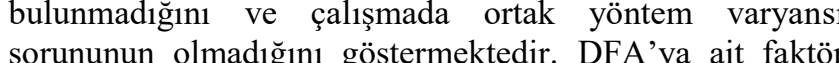
yükleri ve faktör yüklerinin anlamlılığını veren $t$ değerleri incelendiğinde, faktör yüklerinin istatistiksel olarak anlamlı olduğu görülmüştür. Gerçekleştirilen analiz sonuçlarına bağlı olarak 8 faktörlü yapının, DFA ile doğrulandığı ifade edilebilmektedir.

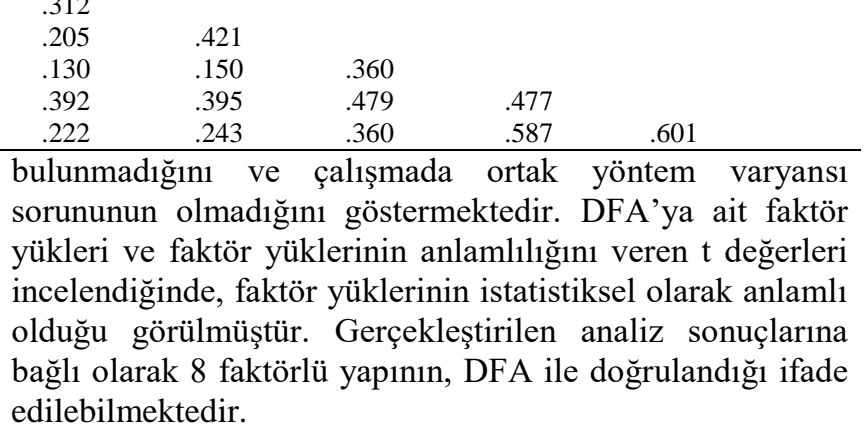




\section{Sonuç, Tartışma ve Öneriler}

Son yıllarda örgütlerin bilgiye duydukları ihtiyaç ve öğrenmeye olan bağımlılıkları, bu konudaki çalışmaları da arttırmıştır. Bu kapsamda deneyim paylaşımı, örgütsel öğrenme ve hafiza oluşum süreçleri irdelenmeye başlamıştır. $\mathrm{Bu}$ bağlamda mevcut çalışmada özellikle çalışanların deneyim paylaşım güdüleri, deneyim türleri ve paylaşım kanallarının tespit edilmesine yönelik bir ölçme aracı geliştirilmiştir. Ölçeğin uygulanabilirliğini sağlamak için geçerlik ve güvenirlik analizleri farklı yöntemlerle kapsamlı bir şekilde incelenmiştir. Ölçeğin geçerliği öncelikle AFA test edilmiştir. Uygun olmayan ifadeler ölçekten çıkarıldıktan sonra, deneyim paylaşım güdüleri ile ilgili 10, paylaşım kanalı ile ilgili 6 ve deneyim türleri ile ilgili 12 ifadenin 8 faktörlü bir yap1 oluşturduğu görülmüştür. Faktörler; aidiyet güdüsü, performans güdüsü, örgütsel güdü, yazılı paylaşım, sözlü paylaşım, geçmiş sorunlar, yeni fikirler ve geçmiş deneyim olarak adlandırılmıştır. Ölçeğin toplam varyansın \%75,14'ünü açıkladığı görülmüştür ve bu değerin oldukça iyi olduğu söylenebilmektedir. AFA sonucunda ortaya çıkan yapının geçerliği DFA ile kontrol edilmiştir ve uyum indekslerinin kabul edilebilir düzeyde olduğu belirlenmiştir. Ölçeğin güvenirliği ise Cronbach Alpha, Rho-A ve Composite Reliability ve Fornell-Larcker Criterion güvenilirlik katsayıları ile değerlendirilmiştir.

Gerçekleştirilen analizler neticesinde geliştirilen ölçeğin, otel işletmelerindeki deneyim paylaşım sürecini belirlemeye yönelik çalışmalarda kullanılabilecek güvenilir ve geçerli bir ölçme aracı olduğu tespit edilmiştir. Geliştirilen ölçek, otel işletmelerinde çalışanların ne tür deneyim paylaşımında bulunduklarını ve bunu hangi motivasyonla gerçekleştirdiklerinin belirlenmesi noktasında önemlidir. Motivasyon unsurlarının belirlenmesi ve yöneticilerin bu unsurlara bağlı olarak tutum ve davranışlar sergilemeleriyle birlikte, örgütün öğrenme kültürünün ve nihayetinde misafir memnuniyetinin ve işletme verimliliğin arttırılmasına katkı sunulmasında rol oynayabilecek bir anlam taşımaktadır. Ölçek, turizm çalışanlarının birbirleriyle bilgi/deneyim paylaşma nedenlerinin, paylaşımlarını hangi kanallar aracılığıyla gerçekleştirdiklerinin yanı sıra paylaştıkları içeriğin konusunun ne olduğunun tespiti hususunda da kapsamlı bir bakış sunmaktadır. Bu bağlamda turizm alanında bilgi paylaşım süreci ile ilgili yapılacak araştırmalarda, özellikle de bilgi paylaşımında bireysel eğilimler üzerinde duran araştırmalarda kullanılabilecek bir ölçek ortaya koyulduğu düşünülmektedir. Ayrıca ölçeğin farklı işletmelerde de kullanılabileceği söylenebilir. Nihayetinde bilgi/deneyim paylaşımının önemi, hizmet işletmeleri başta olmak üzere tüm işletmeler için büyük önem arz etmektedir.

$\mathrm{Bu}$ çalışmanın en önemli kısıtı, sınırlı bir örneklemle yürütülmüş olmasıdır. Ölçeğin, ileriki çalışmalarda daha geniş çalışma gruplarıyla kullanılması önerilebilir. Farklı örneklemelerden alınan sonuçlarla ölçeğin geliştirilebileceği düşünülmektedir.

\section{Kaynakça}

Altenburg, T. (1999). How to promote clusters: policy experiences from Latin America, World Development 27(9), 1693-1713.

Ardichvili, A. (2008). Learning and knowledge sharing in virtual communities of practice: Motivators, Barriers, and Enablers. Advances in Developing Human Resources, 10(4), 541-554.

Avcı, N. \& Küçükusta, D. (2009). Konaklama işletmelerinde örgütsel öğrenme, örgütsel bağl1lık ve işten ayrılma eğilimi arasındaki ilişki. Anatolia: Turizm Araştırmaları Dergisi, 20(1), 33-44.

Avcı, U. (2005). İşletmelerde Örgütsel Öğrenme-Örgütsel Performans İlişkisi: Konaklama Işletmelerinde Örgütsel Ögrenme-Örgütsel Performans Illişkisine Yönelik Inceleme. Doktora Tezi, Süleyman Demirel Üniversitesi, Sosyal Bilimler Enstitüsü.

Avci, U., Kilinç, İ. \& Okumuş, F. (2010). Öğrenme düzeyleri arası ilişki: otel işletmelerinde bir alan araştırması. Ege Academic Review, 10(1).

Ayazlar, G. (2012). Otel işletmelerinde örgütsel öğrenme ve bilgi paylaşımının hizmet inovasyon performansına etkisi: kuşadası 5 yıldızlı otel işletmelerinde bir araştırma. Yayımlanmamış Doktora Tezi. Adnan Menderes Üniversitesi, SBE.

Bartol, K. M. \& Srivastava, A. (2002). Encouraging knowledge sharing: the role of organizational reward systems. Journal of Leadership \& Organizational Studies, 9(1), 64-76.

Brown, J. S. \& Duguid, P. (1991). Organizational learning and communities of practice: toward a unified view of working, learning, and innovation. Organization Science, 2(1), 40-57.

Cangelose, V. \& Diil, W. (1965). Organizational learning observation: towards a theory. administrative science quarterly, Vol. 10, pp. 175-203.

Carneiro, A. (2000). How does knowledge management influence innovation and competitiveness?. Journal of Knowledge Management, 4(2), 87-98.

Chen, W. J. \& Cheng, H. Y. (2012). Factors affecting the knowledge sharing attitude of hotel service personnel. International Journal of Hospitality Management, 31(2), 468-476.

Chiang, C.F. (2010). Perceived organizational change in the hotel endustry: an implication of change schema. International Jornal of Hospitality Management, 29, 157-167.

Chiu, C. M., Wang, E. T., Shih, F. J. \& Fan, Y. W. (2011). Understanding knowledge sharing in virtual communities. Online Information Review. 35(1): 134153. 
Cohen, W. M. \& Levinthal, D. A. (1990). Absorptive capacity: a new perspective on learning and innovation. Administrative Science Quarterly, 128-152.

Cyert, R. \& March, J. (1963), A Behavioral Theory of the Firm, Prentice Hall, Englewood Cliffs, NJ.

Çiftçi, G., Küçükaltan, D., \& Menteş, S. A. (2017). empirical analysis of crisis management practices in tourism enterprises in terms of organizational learning/turizm işletmelerinde $\mathrm{kriz}$ yönetimi uygulamalarının örgütsel öğrenme açısından ampirik olarak analizi. Business \& Management Studies: An International Journal, 5(1), 42.

de Kok, A., Bellefroid, B. \& Helms, R. (2013). Knowledge sharing and channel choice: effects of the new way of working. proceedings of the european conference on knowledge management, ECKM. 2. 849-859.

Dawes, S. S. (1996). Interagency information sharing: expected benefits, manageable risks, Journal of Policy Analysis and Management, 15(3), 377-394.

Dibella, A.J., Nevis, E.C. \& Gould, J. M. (1996). Understanding organizational learning capability. Journal of Management Studies, 33(3), 361379.

Easterby-Smith, M. (1997). Disciplines of organizational learning: contributions and critiques. Human relations, 50(9), 1085-1113.

Erat, S. (2020). Bilgi paylaşımı ve örgütsel güvenin, yenilikçilik davranışı ve bireysel performansa etkisi, meslek lisesi öğretmenleri üzerine bir araştırma. International Review of Economics and Management, 8(1), 124-145.

Fiol, C. M. \& Lyles, M. A. (1985). Organizational learning. Academy of Management Review, 10(4), 803813.

Ford, D. P. \& Chan, Y. E. (2003). Knowledge sharing in a multi-cultural setting: a case study. Knowledge Management Research \& Practice, 1(1), 11-27.

French, J. R. \& Raven, B. (1959). The bases of social power. Classics of Organization Theory, 7, 151-157.

Gjelsvik, M. (2002). Hotels as learning area. Scandinavian Jounal of Hospitality and Tourism, 2(1), 31-48

Gurteen, D. (1999). Creating a knowledge sharing culture. Knowledge Management Magazine, 2(5), 1-4.

Han, T. S., Chiang, H. H. \& Chang, A. (2010). Employee participation in decision making, psychological ownership and knowledge sharing: mediating role of organizational commitment in taiwanese high-tech organizations. The International Journal of Human Resource Management, 21(12), 2218-2233.

Hsu, M. H. \& Chang, C. M. (2014). Examining interpersonal trust as a facilitator and uncertainty as an 1nhibitor of intra-organisational knowledge sharing. Information Systems Journal, 24(2), 119-142.

Hu, M. L. M., Horng, J. S. \& Sun, Y. H. C. (2009). hospitality teams: knowledge sharing and service innovation performance. Tourism Management, 30(1), 41-50.

Huber, G.P. (1991). Organizational learning: the contributing processes and the literatures. Organization science, 2(1), 88-115.

Ipe, M. (2003). Knowledge sharing in organizations: a conceptual framework. Human Resource Development Review, 2(4), 337-359.

İmamoğlu, S. Z., Kayış, A. \& İnce, H. (2018). Yerel yönetimlerde kurumsal duygusal hafıza, bilgi paylaşımı, hizmet geliştirme ve hizmet performansı arasındaki ilişki. Doğuş Üniversitesi Dergisi, 19(2), 95-113.

Jarvenpaa, S. L. \& Staples, D. S. (2001). Exploring perceptions of organizational ownership of information and expertise. Journal of Management Information Systems, 18(1), 151-183.

Karavardar, G. (2012). Çalışan ilişkileri ve bilgi paylaşımı: bankacılık sektöründe bir uygulama. Çankırı Karatekin Üniversitesi IIIBF Dergisi, 2(1), 143-156.

Khandekar, A. \& Sharma, A. (2006). Organizational learning and performance: understanding indian scenario in present global context. Education+ Training, 48(8/9), 682-692.

Kim, T. T. \& Lee, G. (2013). Hospitality employee knowledge-sharing behaviors in the relationship between goal orientations and service innovative behavior. International Journal of Hospitality Management, 34, 324-337.

Kim, T. \& Lee, G. (2012). A modified and extended triandis model for the enablers-process-outcomes relationship in hotel employees' knowledge sharing. The Service Industries Journal, 32(13), 2059-2090.

Kocoglu, I., İmamoglu, S. Z. \& İnce, H. (2011). The relationship between organizational learning and firm performance: the mediating roles of innovation and TQM. Journal of Global Strategic Management, 9(3), 72-88.

Kwok, S. H. \& Gao, S. (2005). Attitude towards knowledge sharing behavior. Journal of Computer Information Systems, 46(2), 45-51.

Levitt, B. \& March, J. G. (1988). Organizational learning. Annual Review of Sociology, 14(1), 319-338.

Liu, C. H. S. (2017). Remodelling progress in tourism and hospitality students' creativity through social capital and transformational leadership. Journal of Hospitality, Leisure, Sport \& Tourism Education, 21, 69-82.

Magnini, V. P. (2008). Practicing effective knowledge sharing in international hotel joint ventures. International Journal of Hospitality Management, 27(2), 249-258.

Magnini, V. P. \& Honeycutt Jr., E. D. (2003). Learning orientation and the hotel expatriate manager experience. Hospitality Management, s.22, ss.267-280.

March, J.G. \& Simon, H. A. (1958). Organizations. New York: John Wiley \& Sons. 
Marsick, V. J. \& Watkins, K. E. (2003). Demonstrating the Value of an Organization's Learning Culture: the Dimensions of the Learning Organization Questionnaire. Advances in Developing Human Resources, 5(2), 132-151.

Matzler, K., Renzl, B., Müller, J., Herting, S., \& Mooradian, T. A. (2008). Personality traits and knowledge sharing. Journal Of Economic Psychology, 29(3), 301-313.

Nahapiet, J. \& Ghoshal, S. (1998). Social capital, intellectual capital, and the organizational advantage. Academy of Management Review, 23(2), 242-266.

Nelson, R. \& Winter S. (1982), An Evolutionary Theory of Economic Change. Cambridge MA: Belknap Press

Özdemir, B. (2006). Örgütsel öğrenme, çevre ve örgütsel performans ilişkisi: otel yöneticilerinin algılamaları üzerinde bir araştırma. Doktora Tezi, Akdeniz Üniversitesi, Sosyal Bilimler Enstitüsü.

Robey, D., Boudreau, M. C., \& Rose, G. M. (2000). Information technology and organizational learning: a review and assessment of research. Accounting, Management and Information Technologies, 10(2), 125155.

Senge, P.M. (1990). The Fifth Discipline: The Art and Practice of the Learning Organization. New York: Doubleday.

Sharratt, M. \& Usoro, A. (2003). Understanding knowledge-sharing in online communities of practice. Electronic Journal on Knowledge Management, 1(2), 187-196.

Sinkula, J. M., Baker, W. E. \& Noordewier, T. (1997). A framework for market-based organizational learning: linking values, knowledge, and behavior. Journal of the academy of Marketing Science, 25(4), 305.

Snyder, J. L. \& Lee-Partridge, J. E. (2009). Understanding choice of information and communication channels in knowledge sharing. ICIS 2009 Proceedings, 105.

Stein, E. W. (1995). Organization memory: review of concepts and recommendations for management. International Journal of Information Management, 15(1), 17-32.

Subramaniam, R. (2005). A multivariate study of the relationship between organizational learning, organizational innovation and organizational climate in the australian hospitality industry. Doktora Tezi, Swinburne University of Technology, Australian Graduate School of Entrepreneurship.

Sveiby, K. E. (2007). Disabling the context for knowledge work: the role of managers' behaviours. Management Decision, 45(10), 1636-1655.

Swift, M., Balkin, D. B. ve Matusik, S. F. (2010). Goal orientations and the motivation to share knowledge. Journal of Knowledge Management. 14(3), 378-393.

Szulanski, G. (1996). Exploring internal stickiness: 1mpediments to the transfer of best practice within the firm. Strategic Management Journal, 17(S2), 27-43.

Tiedemann, N., Van Birgele, M. \& Semeijn, J. (2009). Increasing hotel responsiveness to customers through information sharing. Tourism Review. 64(4), 12-26.

Türkay, O. (2007). Pazara dayalı örgütsel öğrenme: konaklama işletmelerinde pazara dayalı örgütsel öğrenmeyi belirleyen değişkenler ve pazarlama performansına etkileri. Yayınlanmamış Doktora Tezi. Dokuz Eylül Üniversitesi, SBE.

Türkay, O. (2011). Örgüt belleğinin kapsamı ve etkileri üzerine nitel bir araştırma. Verimlilik Dergisi, 2011(2), 7-28.

Uludağ, O., Aktaş, İ. \& Özgit, H. Ö. (2019). Eğitim çalışanlarının örgütsel adalet algılarının ve örgüt kültürünün bilgi paylaşımı üzerindeki etkileri: örgüt kültürünün arac1 rolü. Hacettepe Üniversitesi Ĕgitim Fakültesi Dergisi, 34(1), 160-181.

Wishart, N.A., Elam, J.J. ve Robey, D. (1996). Redrawing the portrait of a learning organization: inside knightridder, Inc. Academy of Management Perspectives, 10(1), 7-20.

Yakut, F. (2016). Örgütsel hafizada bireysel tecrübelerin önemi. In International Congress of Management Economy and Policy Proceedings, 1, (s.245).

Yang, J. T. (2004). Qualitative knowledge capturing and organizational learning: two case studies in Taiwan hotels. Tourism Management, 25(4), 421-428.

Yang, J. T. ve Wan, C. S. (2004). Advancing organizational effectiveness and knowledge management 1mplementation. Tourism Management, 25(5), 593-601.

Yeo, R. K. (2005). revisiting the roots of learning organization: a synthesis of the learning organization literature. The Learning Organization, 12(4), 368-382. 


\section{Extended Abstract}

A significant number of studies have been conducted on the learning of hotel businesses. One of the focuses of these studies is that learning is very closely related to the business culture and the employees' contribution to the cumulative knowledge of the business by performing the learning action with the effect of culture. In this context, employees are in the position of learning intermediaries and their learning also means the learning of the business. One of the ways employees learn is through the sharing of employees with each other. In this context, it is a critical process for employees to share knowledge and experience with each other.

In studies that draw attention to the organizational learning process, the formation and development of organizational memory, which is considered as an important link in the process, has a very close relationship with the experience and knowledge sharing of the employees. This is because the information shared within the enterprise is reflected both in cultural patterns and is transformed into records in registration centers. Transferring the data learned by each employee to the business memory makes learning permanent. So, the sharing of knowledge and experience that emerges as employees learn from each other, is also an important process that improves organizational memory. Therefore, the efficiency of all structures and processes within the scope of organization's learning, which the literature draws attention to, is closely related to the efficiency of employees' experience and knowledge sharing.

Despite its stated importance, it is seen that the organizational learning literature does not sufficiently focus on the experience/knowledge sharing process. It is striking that there is a lack of a literature that treats sharing experience as a process and can penetrate deeply into the object, way and content of sharing. In this study, the issue of employees sharing knowledge/experience with each other as a part of the organizational learning system; the reason for sharing is analysed over how and what is shared, and a scale is developed to measure the efficiency of these three dimensions.

In order to decide which attitudes will be important at the point of sharing knowledge and reveal a wide explanatory explanation regarding the motivational aspect of sharing, the dimensions that have been noted in the literature have been focused. At this point, it has been observed that performance and/or success motivation is an important motivation for information sharing. Based on the literature, items reflecting different indicators of experience sharing motivation were created. Informal and formal channels are mentioned within the scope of information sharing channels. Information is shared from both channels in businesses. Another important distinction is whether the shared information is written or spoken. In this context, the articles related to the sharing channel have been shaped. The broad set of judgments on the content of the sharing has been formed depending on the literature, the opinions of the sector employees and academicians.

Questionnaire technique, one of the quantitative research methods, was used in the study. The validity and reliability of the scale were tested in line with the answers obtained from 333 hotel employees who participated in the study. In order to determine the validity of the scale, Explanatory Factor Analysis (EFA) was performed first. Then, the structure formed as a result of EFA was tested with Confirmatory Factor Analysis (CFA). The reliability of the scale was calculated using Cronbach Alpha, Rho-A and Composite Reliability and Fornell-Larcker Criterion reliability coefficients. After the inappropriate statements were excluded from the scale, it was observed that 10 statements about the motives of sharing experience, 6 about the sharing channel, and 12 statements about the types of experience formed an 8-factor structure. Factors; It has been named as motivation of belonging, motivation of performance, motivation of organizational, written sharing, verbal sharing, past problems, new ideas and past experience. It has been observed that the scale explains $75.14 \%$ of the total variance and this value can be said to be quite good. The validity of the structure that emerged as a result of EFA was checked by CFA and it was determined that the fit indices were at an acceptable level.

As a result of the analyses carried out, it has been determined that the developed scale is a reliable and valid measurement tool that can be used in studies to determine the experience sharing process in hotel businesses. The scale provides a comprehensive overview of the reasons why tourism employees share information/experiences with each other and through which channels they share, as well as determining the subject of the content they share. The most important limitation of the study is that it was conducted with a limited sample. It may be suggested that the scale be used with larger study groups in future studies. It is thought that the scale can be improved with the results obtained from different samples. 